Jurnal KIBASP (Kajian Bahasa, Sastra dan Pengajaran)

Volume 1, Nomor 1, Desember 2017

e-ISSN : 2597-5218

p-ISSN : 2597-520X

DOI: https://doi.org/10.31539/kibasp.v1i1.93

\title{
ANALISIS NILAI MORAL NOVEL BULAN JINGGA \\ DALAM KEPALA KARYA M. FADJROEL RACHMAN
}

\author{
Sri Murti ${ }^{1}$, Siti Maryani ${ }^{2}$ \\ Program Studi Pendidikan Bahasa dan Sastra Indonesia, STKIP-PGRI Lubuklinggau ${ }^{1,2}$ \\ srimurti05@gmail.com ${ }^{1}$
}

Submit, 08-12-2017 Accepted,31-12-2017 Publish,31-12-2017

\begin{abstract}
ABSTRAK
Tujuan penelitian untuk mendeskripsikan nilai moral yang berkaitan dengan hubungan manusia dengan Tuhan, hubungan dengan diri sendiri, hubungan dengan sesama, dan hubungan manusia dengan lingkungan yang terkandung dalam novel Bulan Jingga dalam Kepala karya M. Fadjroel Rachman. Teknik pengumpulan data menggunakan teknik studi pustaka dan catat. Berdasarkan hasil penelitian dan pembahasan terhadap novel Bulan Jingga dalam Kepala karya karya M. Fadjroel Rachman dapat ditarik kesimpulan bahwa nilai moral dalam hubungan manusia dengan Tuhannya ditemukan 28 kutipan, nilai moral hubungan dengan diri sendiri ditemukan 20 kutipan, nilai moral hubungan manusia dengan sesama ditemukan 13 kutipan, nilai moral hubungan dengan lingkungan ditemukan 7 kutipan. Maka dapat disimpulkan bahwa dalam novel Bulan Jingga dalam Kepala karya M. Fadjroel Rachman terkandung nilai moral yang berkaitan dengan hubungan manusia dengan Tuhan, hubungan dengan diri sendiri, hubungan dengan sesama, dan hubungan manusia dengan lingkungan yang terbukti kebenarannya.
\end{abstract}

Kata Kunci : Analisis, Nilai Moral, Novel

\section{ABSTRACT}

The objectives of the study were to describe the moral values associated with human relationships with God, the relationship with oneself, relationships with others, and the human relationships with the environment contained in the novel of Bulan Jingga di Atas Kepala M. Fadjroel Rachman. Technique of collecting data using literature study technique and record. Based on the results of research and discussion of novel Bulan Jingga diAtas Kepala of M. Fadjroel Rachman can be deduced that the moral value in human relations with his Lord found 28 citations, the moral value of relationship with self found 20 citations, the moral value of human relationships with fellow found 13 citations, the moral value of the relationship with the environment found 7 citations. So it can beconcluded that in the novel of the Bulan Jingga di Atas Kepala of M. Fadjroel Rachman contained moral values relating to human relationships with God, the relationship with self, relationships with others, and human relationships with the environmentthat proved to be true.

Keywords: Analysis, Moral Values, Novels 


\section{PENDAHULUAN}

Karya sastra adalah wujud permainan kata-kata pengarang yang berisi maksud tertentu, yang akan disampaikan kepada penikmat sastra. Karya sastra pada hakikatnya adalah gambaran konkrit kehidupan manusia yang diabstraksikan. Karya sastra juga merupakan wujud gagasan seseorang melalui pandangan terhadap lingkungan sosial yang berada di sekelilingnya dengan menggunakan bahasa yang indah. Sastra hadir sebagai hasil perenungan terhadap fenomena yang ada dan merupakan salah satu jenis karya seni.

Karya sastra banyak mengandung nilai-nilai tertentu yang bermanfaat bagi setiap pembacanya, salah satunya adalah nilai budaya. Karena kehidupan masyarakat tidak pernah terlepas dari nilai-nilai budayanya. Artinya sastra merupakan cermin dari budaya masyarakat.

Nilai-nilai yang terkandung dalam karya sastra pada dasarnya mencerminkan realitas sosial yang memberikan pengaruh terhadap masyarakatnya. Sastra sebagai salah satu bentuk kebudayaan adalah seni yang menggambarkan kehidupan manusia. Wujud dari nilai budaya itu ada bahasa, sistem pengetahuan, sistem kemasyarakatan atau organisasi sosial, sistem peralatan hidup dan teknologi, sistem mata pencarian hidup, sistem religi, dan kesenian.

Karya sastra merupakan media untuk mengungkapkan pikiran pengarang. Karya sastra bersifat imajinatif, estetik dan menyenangkan pembaca. Salah satu bentuk karya sastra yang banyak diminati adalah novel. Novel adalah karangan prosa yang panjang mengandung rangkaian cerita kehidupan seseorang dengan orang di sekelilingnya dengan menonjolkan watak dan sifat setiap pelaku. Nurgiyantoro (2009) mendeskripsikan novel sebagai sebuah karya sastra prosa fiksi yang cukup panjang, tidak terlalu panjang namun tidak terlalu pendek. Sedangkan Sumardjo (2005) mengatakan bahwa "novel merupakan bentuk karya sastra terpopuler di dunia. Bentuk karya sastra ini merupakan paling banyak dicetak dan paling banyak beredar, karena daya komunitasnya yang begitu luas di masyarakat”. Dengan pemahaman di atas tersebut dapat disimpulkan bahwa novel merupakan karya sastra bentuk prosa yang menceritakan episode kehidupan manusia atau tokoh yang memberikan keleluasaan terhadap munculnya degenerasi (perubahan) atau tidak harus selalu terpusat pada pkok cerita. 
Karya sastra yang diciptakan oleh pengarang mengandung nilai tertentu yang akan disampaikan kepada pembaca, misalnya nilai moral. Pembaca diharapkan dapat menemukan dan menelaah nilai moral tersebut. Nurgiyantoro, (2007) menyatakan bahwa nilai moral cerita biasanya dimaksudkan sebagai suatu saran yang berhubungan dengan ajaran moral tertentu yang bersifat praktis dan merupakan petunjuk yang sengaja diberikan oleh pengarang tentang berbagai hal yang berhubungan dengan tingkah laku dan sopan santun pergaulan. Menurut Chaplin (2006) mengatakan bahwa moral adalah perbuatan atau tingkah manusia yang sesuai dengan aturan yang mengatur hukum sosial atau adat.

Moral adalah perbuatan, tingkah laku, atau ucapan seseorang dalam berinteraksi dengan manusia. Moral secara ekplisit adalah hal-hal yang berhubungan dengan proses sosialisasi. Individu tanpa moral manusia tidak bisa melakukan proses sosialisasi. Misalnya, seseorang melakukan suatu tindakan sesuai dengan nilai rasa yang berlaku di masyarakat tersebut dan dapat diterima serta menyenangkan lingkungan masyarakatnya, maka orang itu dinilai memiliki moral yang baik, begitu juga sebaliknya. Oleh sebab itu, nilai moral begitulah penting untuk dimiliki dalam jiwa setiap manusia. Di dalam sebuah karya sastra nilai kehidupan seperti nilai moral bisa disampaikan melalui ceritacerita seperti di dalam sebuah novel, karena di dalam sebuah novel terdapat pesan yang disampaikan atau pelajaran yang bisa dipetik dari suatu kisah atau peristiwa.

Moral yang disampaikan kepada pembaca melalui karya fiksi tentunya sangat berguna dan bermanfaat. Demikian juga moral yang terdapat dalam novel Bulan Jingga dalam Kepala akan bermanfaat bagi pembaca. Moral yang ditampilkan dalam novel ini banyak berkaitan dengan persoalan hubungan manusia, misalnya nilai sosial menampilkan persoalan hidup antara hubungan manusia dengan manusia. Hal inilah yang membuat peneliti memilih untuk menganalisis novel ini dengan analisis moral. Novel ini memberikan teladan bagi semua orang untuk bersikap, bergaul dan bertingkah laku dalam kehidupan sehari-hari.

Novel Bulan Jingga dalam Kepala sebagai bahan penelitian karena cerita ini banyak menampilkan persoalan hidup dan kehidupan yang menarik, serta banyak terdapat nilai moral yang tergambar dalam cerita tersebut. Cerita remaja yang menampilkan berbagai aspek kehidupan dan permasalahannya disampaikan dengan bahasa yang menarik dan mudah dipahami, dengan demikian akan memudahkan 
pembaca untuk menemukan nilai moral yang dimaksud. Bulan Jingga dalam Kepala, terkenal dengan kisah sejarah politik Indonesia, serta melukiskan hiruk pikuk gerakan mahasiswa Indonesia dan ceritanya yang menarik sehingga lebih disukai masyarakat pembaca, terutama para remaja atau Mahasiswa.

Adapun rumusan masalah pada penelitian ini adalah Bagaimanakah nilai moral yang berkaitan dengan hubungan manusia dengan Tuhan, hubungan dengan diri sendiri, hubungan dengan sesama manusia dan hubungan dengan lingkungan yang terkandung dalam novel Bulan Jingga dalam Kepala karya M. Fadjroel Rachman?

Sedangkan tujuan dalam penelitian ini adalah "untuk mendeskripsikan nilai moral yang berkaitan dengan hubungan manusia dengan Tuhan, hubungan dengan diri sendiri, hubungan dengan sesama, dan hubungan manusia dengan lingkungan yang terkandung dalam novel Bulan Jingga dalam Kepala karya M. Fadjroel Rachman”.

\section{METODE PENELITIAN}

Metode yang digunakan analisis nilai-nilai moral dalam novel ini melalui metode deskriptif kulitatif. Menurut Sugiyono (2008) metode penelitian adalah cara ilmiah untuk mendapatkan data dengan deskriptif menurut Syaodi (2007) adalah suatu metode penelitian yang ditujukan untuk menggambarkan fenomena-fenomena yang ada, yang berlangsung saat ini atau saat lampau. Adapun sumber data berupa kalimat yang digunakan dalam penelitian ini adalah novel Bulan Jingga dalam Kepala karya M. Fadjroel Rachman. Sedangkan data dalam penelitian ini adalah novel Bulan Jingga dalam Kepala karya M. Fadjroel Rachman. Teknik pengumpulan data yang digunakan dalam penelitian ini adalah teknik pustaka dan catat. Teknik analisis yang digunakan adalah analisis mengalir. Analisis mengalir ini terdiri dari tiga alur kegiatan yang terjadi secara bersamaan, yaitu reduksi data, penyajian data, dan penarikan kesimpulan. Tiga kegiatan ini terjadi bersamaan dan saling menjalin, baik sebelum, selama, dan sesudah pengumpulan data secara paralel. Apabila hal demikian tidak dilakukan maka akibatnya peneliti akan banyak menghadapi kesulitan karena banyaknya data yang berupa deskripsi kalimat. Proses menganalisis data dalam penelitian ini dapat dijelaskan seperti berikut ini. 


\section{HASIL PENELITIAN}

Adapun hasil analisis nilai moral yang ditemukan dalam novel Bulan Jingga dalam Kepala karya M. Fadjroel Rachman sebagai berikut:

\section{Tabel 1}

Nilai Moral Novel Bulan Jingga dalam Kepala Karya M. Fadjroel Rachman

\begin{tabular}{|c|c|c|c|}
\hline No & Nilai Moral & Nomor dan Halaman Kutipan & $\begin{array}{l}\text { Jumlah } \\
\text { Kutipan }\end{array}$ \\
\hline 1 & $\begin{array}{l}\text { Hubungan } \\
\text { manusia dengan } \\
\text { Tuhan }\end{array}$ & $\begin{array}{l}\text { (001) (hal.1), (002) (hal.7), (003) (hal.13), } \\
\text { (hal.40), (005) (hal.54), (006) (hal.59), (007) (hal.68), (008) } \\
\text { (hal.71), (009) (hal.89), (010) (hal.91), (011) (hal.101), } \\
\text { (012) (hal.103), (013) (hal.107), (014) (hal.113), (015) } \\
\text { (hal.114), } \\
\text { (016) (hal.119), (017) (hal.127), (018) (hal.195), (019) } \\
\text { (hal.220), (020) (hal.316), (021) (hal.335), (022) (hal.341), } \\
\text { (023) (hal.348), (024) (hal.335), (025) (hal.356), (026) } \\
\text { (hal.391), (027) (hal.393), (028) (hal.399) }\end{array}$ & 28 \\
\hline 2 & $\begin{array}{l}\text { Hubungan } \\
\text { manusia dengan } \\
\text { dirinya sendiri }\end{array}$ & $\begin{array}{l}\text { (001) (hal.13), (002) (hal.41), (003) (hal.54), } \\
\text { (004) (hal.59), (005) (hal.87), (006) (hal.101), (007) } \\
\text { (hal.103), (008) (hal.113), (009) (hal.119), (010) (hal.119), } \\
\text { (011) (hal.141), (012) (hal.183), (013) (hal.197), (014) } \\
\text { (hal.253), (015) (hal.263), } \\
\text { (016) (hal.333), (017) (hal.341), (018) (hal.341), (019) } \\
\text { (hal.349), (020) (hal.391) }\end{array}$ & 20 \\
\hline 3 & $\begin{array}{l}\text { Hubungan } \\
\text { dengan sesama } \\
\text { manusia }\end{array}$ & $\begin{array}{l}\text { (001) (hal.13), (002) (hal.41), (003) (hal.57), } \\
\text { (004) (hal.87), (005) (hal.113), (006) (hal.127), (007) } \\
\text { (hal.237), (008) (hal.293), (009) (hal.317), (010) (hal.333), } \\
\text { (011) (hal.347), (012) (hal.389), (013) (hal.391) }\end{array}$ & 13 \\
\hline 4 & $\begin{array}{l}\text { Hubungan } \\
\text { manusia dengan } \\
\text { lingkungan }\end{array}$ & $\begin{array}{l}\text { (001) (hal.1), (002) (hal.4), (003) (hal.4), } \\
\text { (hal.139), (005) (hal.263), (006) (hal.335), (007) (hal.345) } \\
\text { Jumlah }\end{array}$ & 7 \\
\hline
\end{tabular}

\section{PEMBAHASAN}

Analisis terhadap novel Bulan Jingga dalam Kepala karya M. Fadjroel Rachman dalam penelitian ini mengenai nilai moral yang terdiri dari hubungan manusia dengan Tuhan, hubungan dengan diri sendiri, hubungan dengan sesama manusia dan hubungan dengan lingkungan. Berikut penjelasan mengenai nilai moral yang terdapat dalam novel Bulan Jingga dalam Kepala karya M. Fadjroel Rachman. 


\section{Hubungan Manusia dengan Tuhan}

Salah satu nilai moral yang terdapat dalam novel Bulan Jingga dalam Kepala karya M. Fadjroel Rachman, adalah hubungan antara manusia dengan Tuhan seperti contoh dalam kutipan sebagai berikut:

(001) Surianata mendengar suara teriakan orang yang disiksa. Suara mereka melengking menembus langit-langit. Aku hanya bisa berharap jeritan mereka tiba ke telinga Tuhan (Bab. 1 (hal. 1).

Kutipan tersebut menjelaskan bahwa Surianata mendengar teriakan orang-orang yang disiksa. Dia merasa kasihan dan berdoa kepada Tuhan agar teriakan mereka didengar oleh Tuhan. Surianata menyadari bahwa dia tak bisa menyelamatkan mereka sehingga hanya berdoa kepada Tuhan yang bisa dia lakukan dan berharap Tuhan akan menyelamatkan orang-orang tersebut dari siksaaan. Memanjatkan doa untuk orang lain dan berharap orang itu mendapatkan kebaikan dan keselamatan dari Tuhan. Mendoakan sesama muslim tanpa sepengatahuan orangnya termasuk dari sunnah hasanah yang telah diamalkan turun-temurun oleh para Nabi dan juga orang-orang saleh yang mengikuti mereka. Mereka senang kalau kaum muslimin mendapatkan kebaikan, sehingga merekapun mendoakan saudaranya di dalam doa mereka tatkala mereka mendoakan diri mereka sendiri. Hal ini di antara sebab terbesar tersebarnya kasih sayang dan kecintaan di antara kaum muslimin, serta menunjukkan kesempuraan iman mereka.

Selain itu kutipan lain yang menjelaskan tentang hubungan manusia dengan Tuhan adalah sebagai berikut:

(002) Aku bersyukur istri dan anakku didampingi oleh sahabat-sahabat seperjuangan yang menjaganya selama aku di penjara (Bab. 2) (hal. 7).

Kutipan tersebut menggambarkan ada kelegaan di hati Surianata ketika dia sedang menjalani masa tahanan di penjara. Surianata cukup lega dan tidak khawatir karena istri dan anaknya didampingi dan dijaga dengan aman oleh sahabat-sahabat seperjuangannya. Surianata bisa berada di penjara, karena melakukan pemberontakan dari segala bentuk kekejaman penguasan negeri ini, ia berjuang bersama sahabatsahabatnya untuk menjatuhkan pemerintahan yang dzolim terhadap rakyatnya. Rasa syukur kadang muncul seperti sebuah ketenangan dalam hati Surianata ketika menghadapi sebuah persoalan. Sikap bersyukur akan membuat hidup Surianata menjadi 
lebih tenang dan damai. Banyak alasan bagi Surianata untuk terus bersyukur terlepas dari apapun keadaannya.

\section{Hubungan dengan Diri Sendiri}

Nilai moral yang terdapat pada novel Bulan Jingga dalam Kepala karya M. Fadjroel Rachman, yang kedua yaitu nilai hubungan manusia dengan dirinya sendiri dalam kutipan sebagai berikut:

(001) Kesabaran dan keihklasanku menerima semua cobaan ini telah terbayar dengan kemenangan (Bab. 3) (hal. 13).

Kutipan di atas menjelaskan bahwa tokoh merupakan sosok yang luar biasa. Dia berusaha bersabar dalam menghadapi ujian dari Tuhan. Tetap kuat dalam menghadapi cobaan apapun dari Tuhan. Dia siap dengan apapun yang Tuhan berikan padanya. Keikhlasan adalah menerima apapun yang telah diberikan kepada kita dengan sungguhsungguh tanpa mengharapkan imbalan. Dalam hal ini yang dimaksud keikhlasan adalah menerima takdir yang telah Tuhan berikan. Sebuah iman dalam tubuh seorang manusia akan berimbas pada sikapnya untuk selalu menerima apapun takdir Tuhan dengan ikhlas. Novel ini akan menjadi contoh bagi pembaca mengenai ketabahan dan keihklasan tokoh dalam menghadapi takdir dari Tuhan. Keadaannya sebagai seorang pesakitan dalam arti yang sebenarnya karena ia menerima sifat keserakahan penguasa ia terima dengan ikhlas dan bersabar. Kemudian contoh kutipan yang menggambarkan tentang hubungan manusia dengan diri sendiri, seperti pada kutipan berikut:

(002) Bukankah sudah begitu sabar, ya Allah. Sabar untuk melewati ini (Bab. 5) (hal. 41).

Kutipan di atas menunjukkan sikap sabar dalam menghadapi ujian dari Allah. Kesabaran memang sikap yang membutuhkan kekuatan jiwa. Maka sikap sabar tidak bisa ditunjukkan oleh orang yang berkepribadian lemah dan rapuh. Untuk memperoleh kesabaran seseorang harus memiliki pengetahuan atas apa yang menimpanya serta yakin bahwa Allah selalu bersamanya. Karena setiap manusia akan menghadapi cobaan hidup. Oleh karena itu, manusia harus siap menghadapi musibah yang menimpanya dengan sabar. Energi kesabaran sangat dibutuhkan oleh setiap muslim dalam menjalani kehidupan sesuai dengan kehendak Allah. 
(003) "Ya Robbi, ikhtiar sudah dilakukan, sekarang kepada-Mu kembalikan semua urusan (Bab. 6) (hal. 54).

Kutipan tersebut menggambarkan hubungan dengan diri sendiri yang terlihat dari seseorang yang berserah diri kepada Allah mengenai keadaan hati dan hidupnya. Ia terus memohon dan meminta kepada Allah dalam setiap situasi dan kondisinya sehingga apapun segala kegiatan dan keluh kesah hatinya ia mengadu kepada-Nya. Ketika melakukan suatu kesalahan, ia tetap berserah diri kepada Allah mengharapkan agar di ampuni dosanya. Karena ia meyakini tiada yang patut ia cintai di dunia hanya Allah dan junjungan-Nya. Apabila seorang hamba bertawakal kepada Allah dengan benar-benar ikhlas dan terus mengingat keagungan Allah, maka hati dan akalnya serta seluruh kekuatannya akan semakin kuat mendorongnya untuk melakukan semua amalan. Dengan besarnya tawakal kepada Allah akan memberikan keyakinan yang besar sekali bahkan membuahkan kekuatan yang luar biasa dalam menghadapi tantangan dan ujian yang berat.

\section{Hubungan dengan Sesama}

Nilai moral yang terdapat pada novel Bulan Jingga dalam Kepala karya M. Fadjroel Rachman, yang ketiga yaitu nilai hubungan manusia dengan sesama dalam kutipan sebagai berikut:

(001) Dari hari ke hari, ikatan di antara mereka semakin erat (Bab. 3)

(hal. 13).

Kutipan di atas menunjukkan bahwa para mahasiswa yang datang ke Jakarta berasal dari daerah yang berbeda, namun perbedaan tersebut tidak membuat mereka saling tidak peduli ataupun tidak saling menghargai. Pada kalimat pertama menggambarkan keakraban mereka, hal tersebut dapat tercipta karena adanya sikap saling menghargai dan berbagi di antara mereka, seperti saling belajar menghargai pendapat dan saling menjaga perasaan sehingga tidak menimbulkan perselisihan di antara mereka. Toleransi adalah suatu sikap saling menghormati dan menghargai antarkelompok atau antarindividu dalam masyarakat atau dalam lingkup lainnya. Sikap toleransi menghindarkan terjadinya diskriminasi sekalipun banyak terdapat kelompok atau golongan yang berbeda dalam suatu kelompok masyarakat. Sikap toleransi secara umum antara lain: menghargai pendapat dan pemikiran orang lain yang berbeda dengan 
kita serta saling tolong-menolong untuk kemanusiaan tanpa memandang suku, ras, agama, dn kepercayaannya.

(002) Meski diwarnai protes, teman-teman baik selama di Istana, akhirnya rela melepaskan (Bab. 5) (hal. 41).

Kutipan tersebut menggambarkan sikap menghargai pendapat orang lain dan sikap toleransi terlihat ketika teman-teman mahasiswa di Jakarta menghargai keputusan untuk pulang lebih awal karena ia mengkhawatirkan kesehatan. Teman-teman mahasiswa tidak bisa menolak keputusan, karena mereka harus mengerti kepentingan orang lain. Pada bagian ini, dapat dikatakan pengarang menyiratkan pesan mengenai pentingnya sikap toleransi untuk menciptakan suasana yang rukun dan damai dalam kehidupan. Sikap menghargai orang lain atau toleransi ini harus dijunjung setinggitingginya, karena dengan adanya toleransi maka perselisihan antar individu dapat dihidari. Toleransi adalah membiarkan orang lain berpendapat lain tanpa adanya intimidasi. Perbedaan sosial, budaya dan agama tanpa adanya diskriminasi terhadap minoritas yang ada pada suatu lingkungan bermasyarakat. Sikap menghargai pendapat orang lain dan tidak mementingkan pendapat pribadi dengan begitu kita akan mendapatkan hasil yang baik.

(003) Hanya satu kata yang bisa kusampaikan untuk sahabatku. Allah menentukan jalan dan arah di mana kita akan menjadi hidup lebih baik. Tanpa-Nya kita bukanlah apa-apa di dunia ini (Bab. 6) (hal. 57).

Berdasarkan kutipan di atas dapat dijelaskan bahwa nasihat antar teman kepada sahabatnya. Memberikan masukan kepada teman karena menurutnya apapun yang menjadi keputusan Allah itu merupakan hal terbaik dari apapun. Karena Allah lebih mengerti dan memahami jalan yang terbaik untuk umatnya, dan ia menegaskan bahwa tanpa Allah kita bukan apa-apa dan tidak mungkin menjadi seperti sekarang. Nasehat tersebut merupakan motivasi untuk sahabatnya agar menjadi manusia yang lebih kuat dan akan berusaha terus memperjuangkan kepentingan rakyat. Ia juga memberikan semangat untuk sahabatnya agar dia bangun dan lebih ceria menjalani perjuangannya. 


\section{Hubungan dengan Lingkungan}

Nilai moral yang terdapat pada novel Bulan Jingga dalam Kepala karya M. Fadjroel Rachman, yang keempat yaitu nilai hubungan manusia dengan lingkungan dalam kutipan sebagai berikut:

(001) Kabut mengepung, putih-tipis mengembang, seribu tangan bekunya mencekik atap, tembok, dan jeruji penjara (Bab. 1) (hal. 1).

Kutipan tersebut mengemukakan salah satu hubungan manusia dengan alam bahwa manusia dituntut harus menyadari kekuatan alam yang maha dahsyat. Suasana malam menjelang subuh hari yang penuh kabut dan embun yang membuat benda-benda mati yang ada di gedung penjara terasa membeku membuat manusia penghuninya atau narapidana mengigil kedinginan. Hal ini mengambarkan bahwa manusia hidup pasti mempunyai hubungan dengan lingkungan atau alam sekitarnya. Relasi manusia dan alam yang seperti ini muncul karena kesadaran bahwa diri manusia hanya merupakan bagian terkecil dari alam semesta, lemah dan tak berdaya, sedangkan alam mempunyai kekuatan dan kuasa yang maha dahsyat. Sehingga tidak ada seorangpun yang mampu menguasai dan menahlukkan kekuatan alam tersebut.

(002) Aku menatap langit berbintang. Serentak, miliaran bintang seperti ingin menusukkan kuku tajamnya. Aku memberontak dan mencoba menaklukkan malam dengan kemajuan zaman (Bab. 2) (hal. 4).

Berdasarkan kutipan tersebut menggambarkan hubungan manusia dengan alam dengan menganggap alam dapat dilawan dan dikuasai sehingga cenderung mengeksplorasi alam, dalam perkembangannya, sebagai upaya menaklukkan alam. Kutipan tersebut memperlihatkan manusia dengan memanfaatkan kemampuan dan kemajuan zaman melalui teknologi yang ada berupaya mengeksploitasi serta mengeksplarasi alam untuk mencapai keinginan dan tujuannya. Sifat dan sikap egois, pada umumnya telah mendorong manusia mengeksploitasi alam sehingga keharmonisan ekosistem menjadi terganggu dan rusak. Manusia menjadi lupa atau pura-pura tidak tahu, bahwa ulahnya akan menghancurkan lingkungan dimana berada. Kerusakan dan ketidakseimbangan tersebut, ditambah dengan penggunaan teknologi yang tidak ramah lingkungan, sehingga berdampak dapat perubahan iklim dan musim. Akibatnya, muncul berbagai bencana alam dan berbagai penyakit karena kesalahan manusia. 
(003) Malam merah memerah. Menjelma embun, menitik dari dagu rembulan, mencekik dunia. Manusia haruslah menyelaraskan diri dengan alam menentukan masa depan manusia (Bab. 2) (hal. 4).

Kutipan tersebut memperlihatkan kecenderungan manusia yang menyelaraskan diri dengan alam, sehingga manusia menjaga dan menciptakan keselarasan dengan alam memperhatikan bahwa manusia mempunyai kepedulian terhadap alam demi kelangsungan hidup masa depan. Upaya keselarasan dengan alam atau menata lingkungan hidup dan kehidupan dapat dilakukan oleh semua manusia. Alam berpengaruh dan dipengaruhi manusia. Segala sesuatu yang ada di alam dapat dimanfaatkan oleh manusia untuk memenuhi kebutuhan hidup manusia, kondisi alam dapat berubah dengan adanya campur tangan manusia dengan segala aktifitasnya yang terkadang melampaui batas.

\section{SIMPULAN}

Berdasarkan hasil penelitian dan pembahasan terhadap novel Bulan Jingga dalam Kepala karya karya M. Fadjroel Rachman dapat ditarik kesimpulan bahwa wujud nilai-nilai moral yang terdapat dalam novel Bulan Jingga dalam Kepala Tuhan meliputi: nilai moral dalam hubungan manusia dengan Tuhannya ditemukan 28 kutipan, nilai moral dalam hubungan dengan diri sendiri ditemukan 20 kutipan, nilai moral hubungan manusia dengan sesama ditemukan 13 kutipan, nilai moral hubungan dengan lingkungan ditemukan 7 kutipan. Maka dapat disimpulkan bahwa dalam novel Bulan Jingga dalam Kepala karya M. Fadjroel Rachman paling banyak mengandung hubungan manusia dengan Tuhan yang dikarenakan pengarang ingin mengungkapkan perilaku sewenang-wenang aparat negara yang jauh dari keimanan kepada Tuhan sehingga rakyat, buruh, petani dan mahasiswa memasrahkan semuanya hanya kepada Tuhan. Selain itu, novel ini juga lebih banyak mengandung hubungan dengan diri sendiri yang dikarenakan pengarang ingin memberikan teladan bagi semua pembaca untuk bersikap, bergaul dan bertingkah laku dalam kehidupan sehari-hari. 


\section{DAFTAR PUSTAKA}

Chaplin. (2006). Dasar-dasar Pendidikan Moral. Yogyakarta: Angkasa

Nurgiyantoro. (2007). Penilaian Bahasa Indonesia. Yogyakarta: Universitas Gajah Mada Press.

------------. (2009). Penilaian dalam Pengajaran Bahasa dan Sastra. Yogyakarta: BPFE.

Sugiyono.(2008). Exspresi Kesusastraan Dalam Kebudayaan. Bandung: Tari Sito.

Sumardjo Jakob. (2005). Pembelajaran Sastra. Yogyakarta: Pustaka Belajar

Syaodih, Nana. (2007). Sastra Lama dan Baru. Jakarta: Gramedia Widia Sarana Indonesia. 